\title{
Paleobathymetric reconstructions and fossil microborings
}

\author{
INGRID GLAUB
}

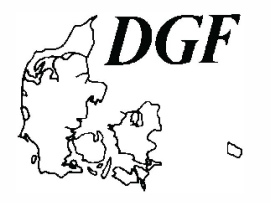

Glaub, I. Paleobathymetric reconstructions and fossil microborings. Bulletin of the Geological Society of Denmark, Vol. 45, pp. 143-146, Copenhagen, 1999-01-30. https://doi.org/10.37570/bgsd-1998-45-17

Ichnotaxonomic and paleoecological studies on Jurassic samples resulted in the identification of four microboring assemblages, called index ichnocoenoses. They are related to specific photic zones or subzones, and therefore are extraordinarily useful for bathymetric reconstructions.

Key words: Fossil microborings, modern microendoliths, paleobathymetry, ichnocoenoses, photic zones.

I. Glaub, Geologisch-Palaeontologisches Institut, Johann Wolfgang GoetheUniversität Frankfurt, Senckenberganlage 32-34, D-60325 Frankfurt, Germany. 1 August, 1998.

Microborings are widely distributed around the globe. Their occurrence is well known from many recent and fossil calcareous hard substrates (for references to the literature see Radtke, Hofmann \& Golubic 1997). By definition, their tunnels range from less than $1 \mu \mathrm{m}$ up to $100 \mu \mathrm{m}$ in diameter. Since the development of the cast embedding technique by Golubic, Brent \& Le Campion-Alsumard (1970) fossil microborings have received increasing attention. The artifical casts, produced by using this method, allow a three-dimensional view of the boring morphology. They are of obvious importance to the morphologic comparison with borings of modern endoliths.

Modern-fossil comparisons led to the delineation of bathymetric correlated index ichnocoenoses presented in this publication. A short description of the main characteristics that typify the distinctive hard substrate ichnocoenoses, and their relation to photic zones and subzones are given.

\section{Material and methods}

About 500 Jurassic brachiopod and molluscan shells from different European basins were studied for microborings, using the cast embedding technique and the SEM (Glaub 1994). The morphological classification of the traces resulted in the differentiation of 34 ichnotaxa. Nearly $70 \%$ of these ichnotaxa showed similarities with borings of modern microendoliths, particulary with those of distinctive cyanobacteria/ cyanophyta, chlorophyta, rhodophyta, and fungi. The finding of modern counterparts gives access to a pool of data about their bathymetric distribution patterns and the relevant controlling factors (e.g. optical water quality, latitude, solar constant). In this context, fossil microborings similar to those of obligate photoautotrophic algae are of special interest.

However, it is often impossible to reconstruct the controlling factors of an ancient environment with sufficient precision. To minimize potential errors when transfering data from modern to ancient environments the following approach was taken:

(1) A clear distinction was made between relative and absolute bathymetric reconstructions. Relative bathymetric reconstructions, classifications to specific photic zones, were preferred. In addition, the absolute depth of the classified photic zone was discussed by considering the controlling factors as far as they are known for the past.

(2) Bathymetric reconstructions were not based on the comparison of a single fossil trace with a single modern endolith, but instead communities of endoliths, typical for specific photic zones were compared with fossil ichnocoenoses.

(3) The classification deriving from the actualistic interpretation was verified by a cross-check with bathymetric reconstructions based on other methods, for example the interpretation of macrobenthos communities. 


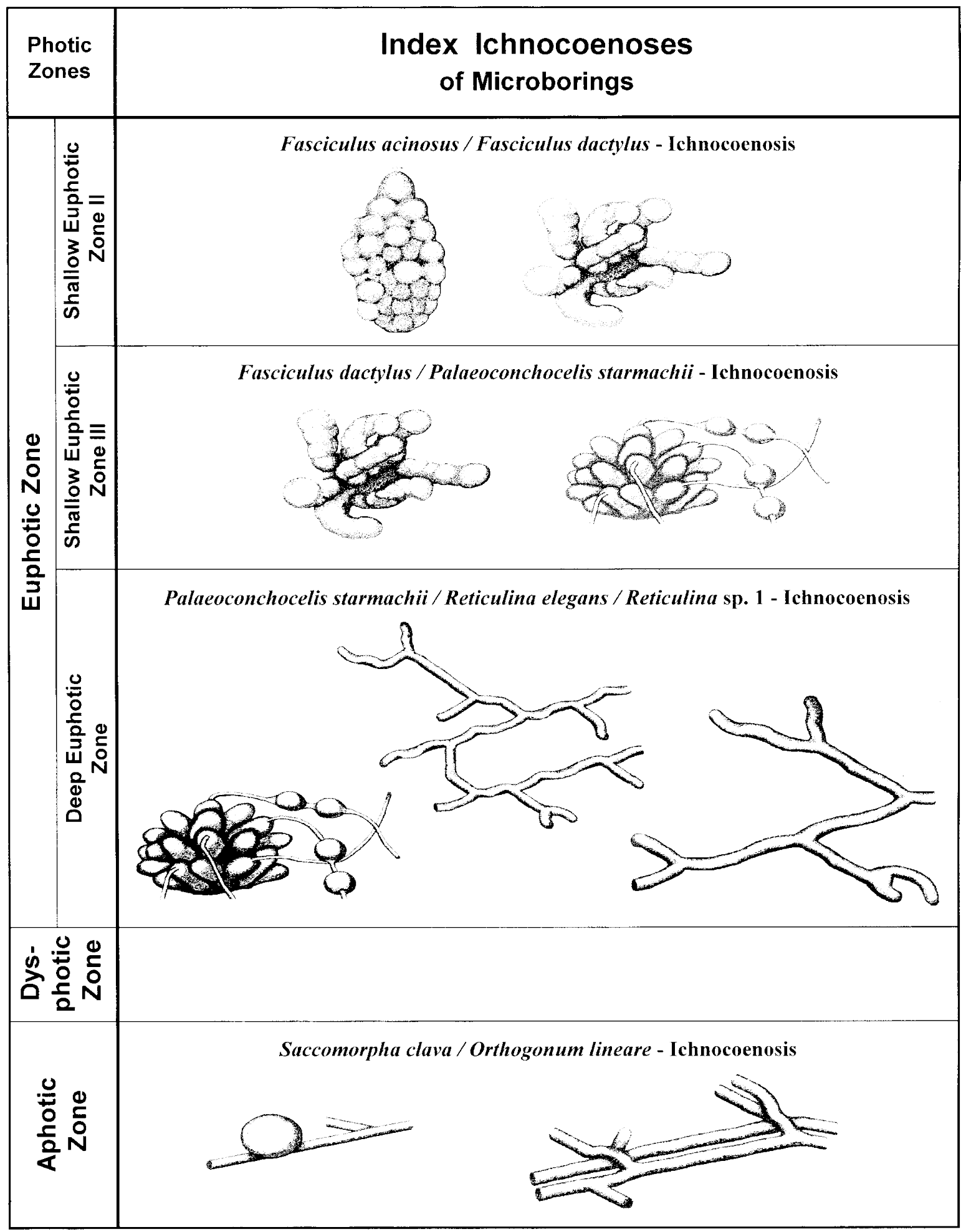

Fig. 1. Index ichnocoenoses of microborings related to photic zones and subzones. The ichnocoenoses are indicated by key ichnotaxa, naming the ichnocoenoses, illustrated by simplified drawings of their artificial casts. 


\section{Results}

The investigations resulted in the delination of a bathymetric scheme of index ichnocoenoses, named by key ichnotaxa (Fig. 1). Index ichnocoenoses were defined for the shallow euphotic zone II and III, the deep euphotic zone, and the aphotic zone (for further details see Glaub 1994).

So far no index ichnocoenoses were characterized for the shallow euphotic zone I (supratidal zone) as well as for the dysphotic zone (in modern environments characterized by approximately $1 \%$ to $0,001 \%$ of the surface light).

In general, the index ichnocoenoses are characterized by the microborings they contain, and by the following relative proportions: (1) of borings attributed to cyanobacteria/cyanophyta (procaryotes) over those attributed to chlorophyta and rhodophyta (eucaryotes); (2) of assumed algal borings oriented perpendicular to the substrate surface over those oriented parallel to the substrate surface; and (3) of borings assigned to obligate photoautotrophs over those classified as obligate or facultative chemoheterotrophs.

\section{Fasciculus acinosus/Fasciculus dactylus- Ichnocoenosis}

The Fasciculus acinosus/Fasciculus dactylus-Ichnocoenosis characterizes the shallow euphotic zone II which is equivalent to the intertidal zone. Predominance of traces well matching modern borings of obligate photoautotrophic cyanobacteria/cyanophyta (procaryotes) is observed. Typically, this borings are developed perpendicular to the substrate surface.

\section{Fasciculus dactylus/Palaeoconchocelis starmachii-Ichnocoenosis}

The Fasciculus dactylus/Palaeoconchocelis starmachii-Ichnocoenosis represents the microboring community of the shallow euphotic zone III which is correlated to the well illuminated portion of the subtidal environment. In contrast to the Fasciculus acinosus/Fasciculus dactylus-Ichnocoenosis (see above) this community is defined by borings similar to procaryotic endoliths (cyanobacteria/cyanophyta) as well as by those corresponding to modern chlorophyta and rhodophyta (eucaryotes).

\section{Reticulina elegans/Reticulina sp. 1/}

Palaeoconchocelis starmachii-Ichnocoenosis

The endolithic assemblage of the deep euphotic zone is called Reticulina elegans/Reticulina sp.1/Palaeoconchocelis starmachii-Ichnocoenosis. This index ichnocoenosis is typical for the less illuminated part of the subtidal regime (in modern environments limited approximately by $10 \%$ down to $1 \%$ of the surface light). The microboring assemblage is characterized by traces affiliated to eucaryotic endoliths, mainly chlorophyta. The dominant boring pattern is parallel to the substrate surface.

\section{Saccomorpha clava/Orthogonum lineare-}

Ichnocoenosis

The data base also revealed the delination of an index ichnocoenosis for the aphotic zone, called Saccomorpha clava/Orthogonum lineare-Ichnocoenosis. Ichnotaxa similar to modern chemoheterotrophic endoliths (e.g. fungi) typify this index ichnocoenosis.

\section{Conclusions}

The scheme of index ichnocoenoses deduced from research on Jurassic samples now awaits testing in environments of other geological ranges. First comparative studies show that the scheme fits quite well to the observations in Triassic and Tertiary environments of deposition (Vogel, Bundschuh, Glaub, Hofmann, Radtke \& Schmidt 1995). In contrast to this, bathymetric comparisons in sedimentary basins of the Upper Cretaceous and the Devonian are more difficult (Vogel et al. 1995). Whereas recent comparative studies indicate that nearly the same scheme of index ichnocoenoses is present in Silurian strata (Glaub \& Bundschuh 1997). An ongoing study concerning Permian and Triassic reef environments will show whether microendolithic ichnocoenoses change at this significant boundary (Balog 1996).

\section{Dansk sammendrag}

Ichnotaxonomiske og palæoøkologiske studier af prøver fra jura resulterede $i$ genkendelse af fire mikroboring-selskaber her kaldt indeks-ichnocoenoser. De er knyttet til specifikke fotiske zoner eller subzoner og er derfor usædvanligt nyttige for rekonstruktion af havdybder.

\section{Acknowledgements}

Many thanks go to the members of the Frankfurt working group, to R. Bromley, and W. Blackwell for valuable suggestions and improving the manuscript. I gratefully acknowledge the support by the "Freunde und Förderer der Universität Frankfurt", for defraying part of my travel expenses to the First International Bioerosion Workshop on Bornholm, 1996. 


\section{References}

Balog, S.-J. 1996: Boring thallophytes in some Permian and Triassic reefs: bathymetry and bioerosion. In Reitner, J., Neuweiler, F. \& Gunkel, F. (eds) Global and Regional Controls on Biogenic Sedimentation. I. Reef Evolution. Research Reports. Göttinger Arbeiten Geologie Paläontologie Sb 2, 305-309.

Glaub, I. 1994: Mikrobohrspuren in ausgewählten Ablagerungsbereichen des europäischen Jura und der Unterkreide (Klassifikation und Palökologie). Courier Forschungsinstitut Senckenberg 174, 1-324.

Glaub, I. \& Bundschuh, M. 1997: Comparative study on Silurian and Jurassic/Lower Cretaceous microborings. Courier Forschungsinstitut Senckenberg 201, 123-135.

Golubic, S., Brent, G. \& Le Campion-Alsumard, T. 1970: Scanning electron microscopy of endolithic algae and fungi using a multipurpose casting embedding technique. Lethaia 3, 203-209.

Radtke, G., Hofmann, K. \& Golubic, S. 1997: A Bibliographic overview of micro- and macroscopic mioerosion. Courier Forschungsinstitut Senckenberg 201, 307-340.

Vogel, K., Bundschuh, M., Glaub, I., Hofmann, K., Radtke, G. \& Schmidt, H. 1995: Hard substrate ichnocoenoses and their relation to light intensity and marine bathymetry. Neues Jahrbuch Geologie Paläontologie, Abhandlungen 195 (1-3): 49-61. 